\title{
CULTURAL RESOURCE MANAGEMENT OF TAIPEI'S INDIGENOUS FOLK TEMPLES
}

\author{
Eleanor B. Morris Wu \\ The University of Chinese Culture, 55 Hwa Kang Road, Yangminshan, Taipei, Taiwan 111
}

\begin{abstract}
Culturally preserving the historical, cultual, and architectural legacy of Chinese folk temples such as Lung-shan Ssu, Pao-an Kung and Hsing-t'ien Kung remains the provenance of the masses of devoted followers of these temples. But government, scholars, government tourist agencies and non-government organizations (NGOs) can also assist in their preservation. Indigenous folk temples in Taipei represent the religious and historical conflation of influences from the "great" tradition (Redfield 1953) of the literati/gentry of Chinese settlers to the island and influences from the "little" tradition of the common people. The Han settlers who came to Taiwan did not come to an uninhabitated area. Austronesian-speaking peoples inhabited the land, such as the pingpu peoples who inhabited the Taipei basin, and eventually intermarried with the Han population and assisted them in their tasks of construction. In the rigors of early settlement to the island of Taiwan, pioneers depended on ling or magical influence and the efficacy of local gods brought with them from the mainland to protect them. Having lost their lineage roots in immigration, folk temples became the source of social solidarity among the Taiwanese settlers and a source of conflict between them, while such folk temples were associated with a Chinese mainland place of origin. As the settlers increased, the literati/gentry immigrated to the island bringing concepts of jen or humanity and propriety in religious rites and rituals that were absorbed by the folk temples of the common people. Lung-shan Ssu, a Buddhist temple or monastery, and Pao-an Kung, a Taoist temple, were built during the Ch'ing dynasty, yet having survived the rigors of Japanese occupation and having developed syncretic forms of their religion to survive, remain popular today. A very popular $20^{\text {th }}$ century folk temple is Hsing-t'ien Kung which represents the aspirations of Taiwanese in a burgeoning industrializing society, such aspirations being reflected in the syncretic origins and practices of the temple.
\end{abstract}

\section{CULTURAL PRESERVATION OF LUNG-SHAN SSU, PAO-AN KUNG, AND HSING-T'IEN KUNG AND OTHER TAIWANESE FOLK TEMPLES}

The means of protecting historical and religious sites are: (1) the historical preservation process... and (2) legislation and litigation (Mills and Ferguson 1998:30).

Due to concern from local citizens on May 26 1982, the Cultural Preservation Act was enacted in Taiwan, during the presidency of Chiang Ching-kuo. Historical buildings, under the aegis of the Council for Cultural Affairs (CCA) and historical sites and spaces, under the aegis of the Ministry of Interior, are given assessment, ranking and protection. Both Lungshan Ssu and Pao-an Kung were declared $2^{\text {nd }}$ Grade Historical Sites on August 19 1985. The cataloguing of historical and religious relics is under the aegis of the Ministry of Education, as the gods and other relics of these temples have already been assessed and catalogued by noted scholars. As historical registration is at the discretion of the city government, Hsing-t'ien Kung has not yet been declared either a historical site or a historical building. Due to the enormous wealth and good condition of Hsing-t'ien Kung, the city government has not yet decided that this temple deserves priority consideration.

Thus, as these temples are not only religious and cultural but also all architectural and public art treasures, they should be promoted by the government's tourist departments as such. Also, urban planning around the location of these temples should be promoted to enhance these temples as lasting tourist attractions. An example to be followed may be the urban planning projects along the 359 meter Hoping Street in Taoyuan County's Tahsi Township. Along this architecturally historical route, shop signs of uniform size and style were installed along with well-constructed and comfortable coffee and tea houses where tourists could sit and look at the lovely architecture of the street (Taipei Review 2002:51). As this restoration was sponsored by the Central government's Council for Cultural Affairs (CCA), scholars might propose the same sort of urban planning for Kwei Ling Road and Hsi Yen Road around Lung-shan Ssu, Hami Street and Chou Chwen 
Street around Pao-an Kung, and Min Chuan East Road and Sung Jang Road around the Hsing-t'ien Kung.

The preservation of religious and historical sites, especially in this case, Taiwanese folk temples, is vigorously attended to by the Council for Cultural Affairs, the Ministry of the Interior and the Ministry of Education. As in a Zuñi Pueblo case in the United States, the historical sites and buildings, here the Taiwanese folk temples, have committees which are in constant liaison with the government Ministries. In the Zuñi Pueblo case a private lobbying group, called the Zuñi Cultural Resource Enterprise (Mills and Ferguson 1998:31), was formed as an intermediary between the government and the main committees of the Zuñi Pueblo people.

In Taiwan, there is a private lobbying nongovernmental organization (NGO) called the Yao Shan Foundation, with CEO Alice Chiu, which attends to the protection of communities and neighborhoods in the vicinity of historical sites, temples and buildings. Although this lobbying group does not act as a direct intermediary between Taiwan folk temples and the government ministries, it lobbies for the preservation and restoration of community neighborhoods in the vicinity of folk temples such as Lung Shan-Ssu, Pao-an Kung, and Hsing-t'ien Kung. As Alice Chiu maintains that the worshippers of these temples are so numerous and prosperous and that these temples have such well-cultivated contact with government agencies, there is little her own NGO needs to do for these temples in regard to funding. However, in terms of keeping people from abusing their relations with these temples, this NGO has stepped in. When several years ago politicians, especially from the DPP (Democratic Progressive Party) were making political speeches on the premises of Lung-shan Ssu, the Yao Shan Foundation called a press conference which helped clear the temple of political speakers. After the press conference, security companies were alerted to the need of this temple and other temples and offered their services to these temples to keep them safe and secure for worshippers. The Yao Shan Foundation was also instrumental, in appears, in inducing these folk temples to install public toilets with their own monies, as administrative red tape was inhibiting this installation. Lung-shan Ssu for example installed public toilets at a cost of 1520 million New Taiwan dollars, which it paid out of its own coffers.

The Yao Shan Foundation feels confident that these folk temples have ample help from the government for preservation of gods and relics but feels the temples, with their enormous wealth, should do more for the neighboring communities. The Yao Shan Foundation is presently preoccupied with assisting neighborhoods in salt farming, sugar confectionary, and beer brewing as a means of raising funds for community projects and helping the low- income members of the community. As in the Zuñi case, the Yao Shan Foundation is privately funded by its own small-business enterprises.

In addition there are groups of high school teachers, called the Shr Ji Sei Wei (Historical Sites Association) who volunteer to act as tour guides for the Pao-an Kung and the Lung-shan Ssu. These guides are preparing to do the same work for the Hsing-t'ien Kung. The government and the public should continue to encourage, enhance and empower all such private Foundations and volunteer organizations to preserve and protect the heritage of the Lung-shan Ssu, Pao-an Kung, Hsing-t'ien Kung, and all other Taiwanese folk temples, religious and historical sites, as well as the architectural, historical and economic integrity of their neighborhoods and communities.

\section{PAO-AN KUNG AND LUNG-SHAN SSU TODAY}

Chinese Folk Temples promulgate the combined religious efficacies of Taoism and Buddhism and to this day, the effect of promulgating Buddhism along with Taoism can be seen in them. In 1981 a new four storey temple was built behind the old Pao-an Kung in Ta-Tao-Cheng. In this building are housed numerous Buddhas, including a statue of Sakayamuni himself. However, alongside these Buddhist effigies remain Taoist gods: for example on the fourth floor of the building is a statue of the supreme Taoist diety, $\mathrm{Yu}$ Huang, the Jade God and his consort Kin Mu Niang Niang. A new library was set up on the the $2^{\text {nd }}$ Floor of the rear building in 1992. The old Pao-an Kung temple and the new (1981) building together are 2000 ping (floor layout measure unit of $2 \times 2$ meters) in total. Across the street from the Pao-an Kung on Ta Lung Street and Hami Street is the Pao-an Kung Park where entertainment for the faithful are held, operas are performed and the ghost month is celebrated. Renovations of the Ch'ing style architecture are an on-going process in Pao-an Kung, and throughout the decade enormous renovations of the old temple have been undertaken. Ta-t'ung chu (Ta-t'ung district) includes the old Ta-tao-ch'eng and Ta-lung-t'ung, the site of Pao-an Kung.

Today, Lung-shan Ssu stands in the old Meng-chia region of downtown Taipei, now called Wan-Hua. Lung-shan Ssu has a visible payroll of more than one hundred workers and is the favorite haunt of local, provincial and national politicians who seek a forum for controversial issues or political campaigns in its enormous courtyard. Today, the temple represents a blend of pan-Chinese ethos, universalistic Buddhism and syncretic modernism. It is a source of considerable wealth, donating great sums to favorite charitable organizations. In 2000-2001 it donated six million New Taiwan dollars to various public schools around Taipei, and 115 million New Taiwan dollars to typhoon and earthquake relief. There is a staff of 40 people responsible for its administration and 
maintenance and a committee of 15 local Wan Hua residents

is in charge of the temple which meets monthly. Architectural renovations of the central hall's Ch'ing style architecture have been an ongoing process during the last few years.

\section{POPULARITY OF HSING-T'IEN KUNG AS A MODERN TWENTIETH CENTURY PHENOMENON}

The "syncretic" Hsing-t'ien Kung which is located in downtown Taipei in the Chung-shan district is a modern phenomenon. Although Feuchtwang (1974:297, n.34) tells us that the origins of the Hsingt'ien Kung were founded as a vegetarian hall and a semi-secret writing cult for the "cultivation of virtue and the breaking down of superstition" in 1937, according to later literature, Hsing-t'ien Kung began as a small temple in San Hsia in 1945, dedicated to the worship of its still present chief deity, Kuang Kung, a legendary military hero and accountant and source of ling and important to the burgeoning economic skills of modern day Taiwan. The temple was originally named the Shin-sho Tang. Founded by coal mining magnate, Huang Chong (1911-1970), in 1949, the temple was the recipient of donated land by Huang Chong who opened a small Kuan Ti Miao (General Kuan Deity Shrine) and expanded it to include another location in Taipei in Cho Tai Street. In 1956 the one hall temple moved to Pei Tou (northwest of Taipei) and in 1958 it was extended to three halls. In 1960, the Pei Tou temple building was completed and in 1967 another sister temple was opened in Min Chuan East Road, the present location of the main temple in downtown Taipei. In 1968, the name was changed to the present name, Hsing-t'ien Kung.

Popular with middle-class office workers and executives who can be seen thronging its halls on every working day along with women and the elderly, the social status of Hsing-t'ien kung is also assured by its multiple social welfare and charitable works. Two libraries exist: one on the Sungchiang Branch of the Temple was opened in 1980 and the one in the Pei Tou Branch was opened in 1987. Library automation was commenced in 1996. The seventeen floor En Chu Kung Hospital was opened with a total of 486 beds in Sanhsia (southeast of Taipei) in 1998.

Due to the masses of followers that adhere to the teachings of the Chinese folk temples in Taiwan generally and Taipei, there is little imminent danger of their extinction, even in the presence of the vast commercial activity, global economy and postmodern architecture that characterizes modern Taipei and Taiwan. Chinese folk temples such as the $18^{\text {th }}$ century Pao-an Kung and Lung-shan Ssu and the $19^{\text {th }}$ century Hsing-t'ien Kung, have their own logic and strategy for surviving the vicissitudes of $20^{\text {th }}$ century modernization: this is their faith, their acutely remembered history and their allegiance to their own native culture. To ensure that the legacy offered by these temples is preserved by the general society, both government, scholars, the public and government tourist agencies should participate in helping to preserve and enhance this legacy. As the central government has already afforded Pao-an Kung and Lung-shan Ssu the designation of $2^{\text {nd }}$ Grade Historical Site, a new designation ought to be awarded to Hsingt'ien Kung as well, despite its having been built in the $20^{\text {th }}$ century. A new phenomenon in tourism is "architourism" where tourists pay to see remarkable architectural buildings around the globe (International Herald Tribune 2002:8). Pao-an Kung, Lung-shan Ssu, and Hsing-t'ien Kung, with their special pillar and beam constructions and well-organized wall paintings and marvellous statues of both Taoist and Buddhist gods and goddesses are world-class architectural and public art sites and could definitely qualify for this kind of tourist promotion.

\section{HISTORICAL BACKGROUND}

Anthropological research shows all aspects of the folk temples such as Pao-an Kung, Lung-shan Ssu and Hsing-t'ien Kung belong to the "little tradition" of the common people, i.e., those masses of the lower economic classes who were illiterate (Redfield 1953). However, these temples of the "little tradition" were historically legitimated by their proper correspondences with official temples of the "great tradition," a tradition associated by Redfield with the upper strata of the society, rich merchants, landlords, officials, the literate, or the gentry/literati. The tradition of the pre-revolutionary gentry/literati is, however, now remembered only in its archaic vestiges in modern Taiwan. It can be argued that the symbolic lexicon of Taiwanese folk temples expresses the structural contradictions of Taiwanese society and illustrates the transition that has occurred in Taiwan from the old wet rice agricultural economy to Taiwan's modern industrial state. Furthermore it can be argued that folk temples are the means by which this transition is expressed and this purpose accounts for their continuing relevance to life in modern Taipei and Taiwan.

The cult of the popular folk temple was a Chinawide phenomena in the "little tradition," and with Han immigration to Taiwan burgeoning in the 1600s, this phenomena spread to Taiwan. The deity or deities of the temples were believed to have ling or "magic power" and "efficacy" (Morris 1993:10-11; Sangren 1987:2-5, 211-213). If misfortune fell upon the worshippers this would be attributed to the deity or deities or the place of the temple itself perhaps because of its bad geomancy of feng shwei, literally "wind and water" orientation of building. ${ }^{1}$ The deities and/or the temple would then be abandoned. 
According to Japanese records consulted by Lamley (1977:170), Lung-shan Ssu was founded in 1740 in Meng-chia by people from San-I counties in Chuan-chou prefecture in Fukien. Similarly, according to Japanese records consulted by Lamley (1977:170), Pao-an Kung was founded in 1805. The main deity of the Lung-shan Ssu is the Buddhist goddess, Kuan Yin. The main god of the Pao-an Kung was the doctor god, Pao-Shen, who was also a Taoist priest born in Tung-an country, Fukien province in AD 979 according to temple records.

However, Han immigrants from Chang-chou, Ch'uan-chou in Fukien and Chao-chou in Kwantung (Shepherd 1993:144) did not enter an unoccupied land in Taiwan as groups of Austronesian-speaking peoples populated the entire island with their own customs and religions. In the Taipei basin and the Western coast where the Han landed, the pingpu (people of the plains) lived by hunting the roaming deer at that time and by fishing and swidden agriculture (Shepherd 1993:31; Blundell 2000:8). These peoples were animist with a main water deity. From an estimate of the Dutch censuses taken in the seventeenth century, there were about 100,000 total indigenous people at that time and inter-village warfare and head-hunting were universal. The pingpu people, among them the Katagelan tribe, who inhabited the Taipei basin (hence "plains aborigines" or pingpu fan) resided in semi-permanent villages, tribes or she organized only above the village level for the purposes of occasional alliances.

Although the craftsmen who designed the Pao-an Kung and the Lung-shan Ssu were from the home districts of mainland China or Taiwan, there is some circumstantial evidence that the pingpu or Katagelan who lived in the Taipei basin may have helped in the actual building of the temples and may even have worshipped there as they were fully acculturated by that time and had villages in Ta-lung-tung. While all other direct evidence of the participation of the indigenous Ketagalan people in the building of the Pao-an Kung and the Lung-shan Ssu is obscure, there are indications of the Ketagalan people assisting in the building of at least one temple in Pei Tou, the Temple now known as the Kuan Tu Temple. According to Zhou Zhong-xuan (Chou Chong-suan), "Before the Leng-Sen Temple, located at the entrance of Kantau (Guan du), there was once a great harbour ... this temple was established in 1712 in order to worship Matsu. On inauguration day, all of the aborigines went there together...” (Zhu Luo Xion Zhi (Chu Luo Sian Chi) (Gazette Zhu luo) 1962:286). This Kuan Tu Temple, built in honour of Matsu 336 years ago by Buddhist Master Shih Shing, in the Ch'ing dynasty, was first of thatch.

There are only two pillars of the old temple remaining in the foyer of the Temple in front of the main Goddess Matsu, and on these pillars, dated in the Chen Long of the Ch'ing Dynasty in 1773, there is one surname inscribed "Pan." While there were Chinese from the mainland with the surname Pan, those pingpu who assimilated to Han ways were also often given this surname by the early Han settlers. Thus, the role played by pingpu people in the founding of the Kuan Tu temple deserves further investigation.

Ketagalan people lived in many villages spread throughout early Ta-lung-tung where the Pao-anKung was to be constructed (Ang 1995:56). In the early $17^{\text {th }}$ century, while Ta-lung-tung was already an active commercial district, Meng-ga (Meng-chia), where Lung-shan Ssu would be constructed, was uncultivated and relatively deserted as the Tan-shui River was too shallow for the bigger boats to dock there. Although both Ta-lung-tung is a Chinese name meaning "Great Dragon Way," "Meng Ga," "Meng Ka” (Meng-chia) is believed to be a pingpu name meaning "canoe." As well, the earliest known name for the Ta-lung-tung was “Ta-lung-pon,” where "pon" is not a Chinese words and whose origin is unknown and is probably a Ketagalan name (Ang 1995:56). In addition in the areas of Ta-lung-tung many Ketagalan villages were well established (Ang 1995:56). The Ketagalan tribe, like some other pingpu people, was matrilineal and uxorilocal (Shepherd 1993:386-387), while the Han people were patrilineal and patrilocal.

As workmen for the temples were recruited from the local population and the population was an intermixture of Han and Ketagalan, it is safe to assume that some of the workers on the temple at least were indigenous tribesmen (Shepherd 1993:362-4, 376f, 382f, 387f, 407, 521n5, 524, 527). In fact, so complete was assimilation in many cases that the Ketagalan took on Chinese names and in their adopted Chinese funeral customs, assigned their forebears' place of origin to China (Shepherd 1993:383, 383 n107). Hence today, many Ketagalan are unaware of their true indigenous origins.

\section{LUNG-SHAN SSU: HISTORICAL AND MILITARY BACKGROUND}

Early in the $18^{\text {th }}$ century, Ch'uan-chou and Changchou Chinese from Fukien or Canton or Han (Hoklo) settlers had begun to settle lands among navigable parts of the Tan-shui River. Additional Chang-chou settlers arrived at this time in the 18th century along with groups of Hakka.

During the $18^{\text {th }}$ and $19^{\text {th }}$ centuries, folk temples, which actually were a pragmatic substitute for the social stability provided by lineage temples, became the new focus of social solidarity. Temples became the bastions of military solidarity and might and settlers in battle with each other over land or water rights carried the gods and goddesses of their temples before them in battle. Feuchtwang (1974:269) quotes Lin Heng-tao as saying that popular temples provided a form of self-government for the immigrant communities. Settlers had few kin and depended on 
their neighbors for mutual aid, functions that on the mainland were undertaken by local lineages. Special shrines were erected for settlers who died in battle and who did not have established lineages or families to bury them. These were called the Yu-Yin Kung.

Besides Kuan Yin, other deities, such as the goddess of sailors, Matsu-also known as T'ien Ho (Empress of Heaven) - who was regarded as the savior goddess of Taiwan and who fully met the criteria of ling as outlined above were added to the Lung-shan Ssu temple pantheon. ${ }^{2}$

\section{THE RELIGIOUS AND ECONOMIC COMPONENTS OF CHINESE FOLK TEMPLES}

It is important to note here that, according to the theologian, Dr. Tong Fung-wan (1988), Taiwanese folk religion is a product of syncretism, containing elements from all three of the primary Chinese religions, i.e., Taoism, Confucianism and Buddhism. According to Dr. Tong (1988: 12), it also contains elements of "animism" which he defines as "folk beliefs, including all the elements of primitive religious phenomena ... for example, nature worship, ancestor worship, fetishism, and magic.” As a result of these combinations of elements, the "cult" of the Chinese folk temples comprises a pantheon of gods, goddesses and other objects of worship that "exhibit the characteristics of anthropomorphism, geographical relatedness, efficacy, and laissez-faire" (Tong 1988:9). ${ }^{3}$ According to the Republic of China Yearbook (1999:462-467), while there are 4.86 million pure Buddhist adherents $(22.37 \%$ of the population) in Taiwan and 4.5 million pure Taoist adherents (20.72\% of the population), the majority of the population are eclectic, believing in both Taoism and Buddhism and practicing their religion in Taiwanese folk temples (ibid.: 468).

Under the difficult conditions of pioneer days in Taiwan, there was often little expectation for the lineage - the main bulwark of social solidarity in Chinese society - to expand. The Chinese folk temple became a strong source of emotional and spiritual support in those circumstances, as was the ritual bond between the "root shrine" or original temple and the Taiwanese branch.

\section{CHINESE FOLK RELIGION COMPARED WITH THE OFFICIAL STATE RELIGION}

While Chinese folk religion relied in varying degrees on ling or magic and efficacy to obtain its ends, the Confucian state religion relied on varying degrees of jen or humanity as well as the other principle virtues to obtain its ends. ${ }^{4}$ Folk temples were not permitted to produce a pantheon of gods that was outside the basic pantheon structure of the official temples. Official temples would often adopt or elevate (i.e., promote) deities that had first been proposed by the folk temples. While the former actions were performed by Redfield's (1953) “little tradition” for a various complex of reasons that involved respect, adulation, imitation and fear, the latter actions were initiated by Redfield's "great tradition" in order to pacify the lower classes, keep them from subversion, and prevent disorder. From the point of view of the gentry/literati and official classes of the "great tradition”, religion was a means of social control.

While Taoism had been the official religion of the imperial court prior to the Ch'ing dynasty, it had never been fully accepted as such by the literati/gentry who comprised the bureaucracy and who had always remained true to Confucianism. The literati distrusted Chinese folk religions above all because their conformity with Confucian ethics and mores was never considered entirely sincere.

\section{HISTORICAL INFLUENCE OF THE JAPANESE ON LUNG-SHAN SSU AND PAO-AN KUNG}

By 1884, the year the Sino-French War broke out, and northern Taiwan was attacked, T'ai-pei-fu had the appearance of a Chinese walled city, complete with City God temple. While the Japanese had accepted the Buddhist religion from the Chinese, Taoism had never been accepted in Japan. After the Treaty of Shiminosaki and the cessation of Taiwan to Japan in 1895, as part of an overall plan for the conquest of China and Southeast Asia, Japan's kominka (worship of the Emperor) assimilation program was to be implemented in Taiwan (Kerr 1974:162-167, 202).

In their attempt to acculturate Taiwan, the Japanese set about eradicating all vestiges of traditional Chinese culture. Between 1899 and 1905 (Kerr 1974:75 and passim), Liu Ming-ch'uan's heavy city walls, which were the Taiwanese symbol of the official state religion and the source of its major altars, were demolished, while the City God temple was also destroyed.

As Taoist oriented temples were forcibly closed by the Japanese, many Chinese folk temples, such as Lung-shan Ssu and Pao-an Kung, proclaimed their Buddhist orientation and officially denounced their Taoist affiliation. Buddhist effigies were placed in the most prominent front part of their folk temples and Taoist deities were either hid entirely or else discretely placed in the rear parts of the temple. This way the temples could hope to escape closure.

In 1945, when Lung-shan Ssu was bombed by the allies, the temple was totally destroyed, but the statues of the gods remained again unscathed. This was also regarded as ling, or miracle, attributable to the direct intervention of Buddha.

Distinguished Temple Boards of Governors were installed for both Pao-an Kung and Lung-shan Ssu, composed of wealthy businessmen, some of whom were members of traditional guilds and associations as well as many municipal officials. Generous donations from the Central, Provincial and Municipal Governments, as well as from private benefactors, to reconstruct the temples as a tourist attraction, have 
allowed temple management to undertake considerable reconstruction.

Rather than eradicating the old official state religion in republican times, the present Republican government has taken an increasingly laissez faire attitude towards criteria of legitimation ${ }^{5}$ not only for folk religions but also for sectarian or syncretic religions, i.e., those religions that fall entirely outside the boundaries of official Confucian legitimation as it had existed under the Ch'ing (AD 1663-1911). ${ }^{6}$

\section{NOTES}

1. Feng shwei (wind and water) is the Chinese term for geomancy, the ancient Chinese art of determining the configuration of land and water in the interests of improving or augmenting one's destiny.

2. The myth of the virgin, Ma Tsu, is that she saved her brother from drowning in his sleep while she dreamt and later gave up her life to restore her injured father. Similar in status to the Bodhisattva, K'uan-yin, Ma Tsu is believed to have an extraordinary range of ling, especially for sailors and for Taiwanese. She has generally been adopted as the national goddess of Taiwan and is seen by some Taiwanese as a symbol of the unique identity, even political independence, of Taiwan.

3. By "anthropomorphism" Tong means the transformation of spirits or fetishes into deities with real or simulated human personalities. By "geographical relatedness" Tong means the deities have a special relationship to the territories from which the worshipers themselves originated or believed themselves to be originated from. By "efficacy" he means ling (magic) and by "laissez-faire" he designates the lack of strict code, liturgy or other types of rigid religious laws associated with the deity.

4. It should be added here that those processes of "disorder" in China, such as they were understood by the literati. were always attributed to a failure of jen in particular and of other principle Confucian virtues in general.

5. For a more thorough exposition of the sociological meaning of legitimation as it spans simpler societies to more complex societies in the works of Freud, Mead, Weber, and Durkheim (see Habermas 1973).

6. Syncretic religion or sectarianism as an issue in Chinese religion can be explained in general however as establishment of a cult, sect or temple in a mode that does not conform with the strictures of any religion, official or popular, or that does not meet the basic criteria of religion as determined by the literati of the "great tradition." For example, basic tenets of Confucianism must be an integral part of all legitimate religions. Deities worshipped in all legitimate folk cults must have received official approval or canonization by an Imperial dynasty for their display of virtues compatible with Confucianist beliefs. Legitimation of popular religions was a critical matter for the Ch'ing as they attempted, with decreasing success as the dynasty wore on, to prevent sectarianism from overwhelming popular religion. Throughout Chinese history sectarianism invariably transformed itself into anti-dynastic political movements, the most notorious ones being the Taiping rebellion of the mid 19th century and the Boxer Rebellion of 1902.

\section{REFERENCES}

Ang, James Ka-im (Weng Chia-yin) 1995. Taipei Ku Di Tu Kao Su. Taipei: Taipei Wensien Wei (Chinese).

Blundell, David, ed. 2000. Austronesian Taiwan: Linguistics, History, Ethnology, Prehistory. Berkeley: Phoebe A. Hearst Museum of Anthropology.

Feuchtwang, S. 1974. City Temple in Taiwan under three regimes. In M. Elvin and G.W. Skinner (eds), The Chinese City Between Two Worlds. Stanford: Stanford University Press.

Habermas, J. 1973. Legitimation Crisis. Thomas McCarthy, trans. Boston: Beacon Press.

Kerr, G. H. 1974. Formosa: Licensed Revolution and the Home Rule Movement 1985-1945. Honolulu: University of Hawai'i Press.

Lamley, H. J. 1977. The formation of cities: initiation and motivation in building three walled cities in Taiwan. In G. W. Skinner (ed.), The City in Late Imperial China. Stanford: Stanford University Press.

Mills, Barbara J., and T. J. Ferguson 1998. Preservation and research of sacred sites by the Zuni Indian tribe of New Mexico. Human Organization 57(1):30-42.

Morris, E. B. 1993. Cross-cultural insights into anthropological methodology: the dialectics of ling and jen. Chinese Culture XXXIV, September, 1-37.

Redfield, R. 1953.The Primitive World and its Transformations. Ithaca: Cornell University Press.

Republic of China Yearbook 1993,1999. Taipei: Government Information Office.

Sangren, P. S. 1987.History and Magic Power in a Chinese Community. Stanford: Stanford University Press.

Shepherd, J. R. 1993. Statecraft and Political Economy on the Taiwan Frontier 1600-1800. Stanford: Stanford University Press.

Tong, Fung-Wan 1988. Vibrant, Popular Pantheon. Free China Review, January. Taipei: Government Information Office.

Zhou, Zhong-xuan (Chou, Chong-Suan) ed. 1962. Zhu Luo Xian Zhi (Chu Luo Sian Chi) (Gazette Zhu Luo). Taipei: Taiwan Bank (in Chinese). 